\title{
Dostoiévski e os dilemas do existir contemporâneo ou da finitude sem redenção
}

\section{Dostoevsky and the dilemmas of contemporary existence or finitude without redemption}

Autor: Marco Antônio Casanova Edição: RUS Vol. 12. № 18 


\title{
Dostoiévski e os dilemas do existir contemporâneo ou da finitude sem redenção
}

\author{
Marco Antônio Casanova*
}

Resumo: 0 intuito central do presente texto é apresentar o problema da ação no mundo contemporâneo em diálogo direto com a obra Os demônios de Fiódor Dostoiévski. Para tanto, o texto inicia-se com a defesa de uma posição de princípio em relação ao conteúdo fenomenológico radical da obra de arte literária, antes de tudo da contemporânea. Em seguida, conquistada uma base diferencial para a exposição de nosso problema, tentamos antes de tudo mostrar o nexo estrutural entre três fatores próprios ao mundo demoníaco que emerge da obra dostoievskiana: o modo peculiar de recepção da Revolução Francesa; a ambientação inicial de $O s$ demônios a partir do campo existencial de duas figuras antes periféricas na trama do livro, mas completamente decisivas para a formação dos demônios particulares; e, por fim, o problema da ação e da falta completa de medida que se concretiza em duas possibilidades específicas, Stavrógin e Kiríllov.

\begin{abstract}
The central aim of the present paper is to present the problematic character of action in the contemporary world in direct dialog with Fyodor Dostoyevsky's work The Possessed. In order to fulfill it, the paper starts with a principle position concerning the radical phenomenological content of literary work of art, above all the contemporary one. Secondly, once attained this differential basis for the exposition of our problem, we try to show the structural connection between three factors in the demonic world which emerges from Dostoyevsky's work: a peculiar reception of the French Revolution; an initial articulation of the ambient of The possessed from two peripheral figures in the main plot of the book, but completely decisive for the development of particular possessed figures; and, finally, the problematic character of action and the lack of measure present in two existential possibilities, Stavrogin and Kirillov.
\end{abstract}

Palavras-chave: Ausência de medida; Niilismo; Ateísmo científico; Ação; Revolução; Desesperança

Keywords: Lack of measure; Nihilism; Scientific atheism; Action; Revolution; Despair 
Sombrio, eu caminhava, recentemente, por um crepúsculo pálido como um cadáver - sombrio e rijo, com os lábios cerrados. Não apenas um sol havia declinado para mim. Uma senda, que subia obstinada entre os seixos, uma senda má, solitária, sem mais o

consolo nem de ervas nem de arbustos, uma senda alpestre rangia sob a obstinação de meus pés. Mudos, andando sobre o zombeteiro chiar do cascalho, pisando os pedregulhos que os faziam deslizar: assim meus pés forçavam o caminho para o alto.

(Nietzsche, Assim falou Zaratustra, "Da visão e do enigma", pp. 148-9)

\section{Considerações iniciais sobre a relação entre filosofia e literatura}

* Professor do Departamento de Filosofia da Universidade Estadual do Rio de Janeiro - UERJ. Doutor em filosofia pela Universidade Estadual do Rio de Janeiro - UFRJ/Universidade de Tübingen, Pós-doutorado - Universidade de Freiburg e Presidente da Sociedade Brasileira de Fenomenologia. Autor de A eternidade frágil: Ensaio sobre temporalidade na arte (2013), entre outros; https:// orcid.org/0000-0003-0765-9636; casanovamarco_271@hotmail. com; http://buscatextual.cnpq. br/buscatextual/visualizacv. do?id=K4723468D2
A relação entre filosofia e literatura é tão imediata quanto tortuosa, tão simples quanto perigosa, tão essencial quanto sujeita aos descaminhos os mais terríveis. Na medida em que uma série de passagens literárias tendem a trazer consigo um manancial reflexivo imenso, é sempre possível pensar a literatura como encerrando em si um conjunto significativo de exemplos, que podem ou bem corroborar certas posições argumentativamente estabelecidas ou bem funcionar como ponto de partida para um desdobramento conceitual subsequente. É célebre a utilização platônica da narrativa mítica como ponto de partida de um diálogo ou como encerramento de uma via aporética. Sua utilização do mito nessas duas chaves de leitura atravessa a descrição do cortejo das almas no Fedro, da ascensão à liberdade no mito da caverna na República, passa pelo mito da política no Protágoras e se distribui por toda a obra de maneira homogênea. Em todos esses casos, o mito funciona como estopim ou como ponto de consumação da argumentação, de tal modo que a relação entre filosofia e literatura tende a ser pensada a partir da suposição de que caberia ao pensamento filosófico desdobrar precisamente a verdade 
que se encontra intuitivamente presa na imediatidade da experiência mítica. Soren Kierkegaard e Friedrich Nietzsche levaram essa posição adiante, uma vez que mesclaram com sua atividade pensante a utilização de uma produção literária correspondente. Kierkegaard utilizou-se por um lado da escrita literária como forma de construção de uma linguagem indireta que seria capaz de concretizar em si mesma as possibilidade múltiplas de uma existência marcada pelos dilemas oriundos dos três estágios estruturais de uma existência sempre acompanhada de perto pelo desespero e a angústia, enquanto Nietzsche plasmou, por outro, em seu Zaratustra, o caminho mesmo daquele personagem que realizava em si a condição e os destinos do ser humano diante de um mundo sem deus, sem transcendências autonomizadas, sem metanarrativas, sem princípios primeiros e fins últimos. Jean-Paul Sartre e Albert Camus souberam ao mesmo tempo se valer muitas vezes da literatura em geral como um campo de experiências filosóficas próprias, de tal modo que vemos em muitas de suas obras literárias a concretização de teses específicas gestadas muitas vezes no campo da atividade filosófica. Gerd Bornheim acentua em seu belo livro sobre Sartre, em uma passagem sobre a noção sartriana de olhar (le regard), o quanto o volume 3 da trilogia Caminhos da liberdade, intitulado Com a morte na alma, concretiza de maneira extremamente plástica a experiência humana de jamais ter certeza de que se está ou não se está sendo visto. ${ }^{1}$ Por fim, Gilles Deleuze procurou se valer da literatura antes de tudo contemporânea como o campo de uma aliança radical possível com o pensamento, como o espaço de linhas de fuga, devires e movimentos de desterritorialização, que acabam sempre por revelar as potências do fundo que ameaçam constantemente a estabilidade de uma superfície encurtada por sínteses do hábito e por generalizações incessantes do particular. ${ }^{2}$ É isso que encontramos formulado em uma passagem paradigmática de Conversações: "A questão não é de uma comparação de gêneros. A alternativa não

1 Cf. Gerd Bornheim, Sartre. São Paulo: Perspectiva, 2011, p. 112.

2 Cf. quanto a esse ponto o livro chave de Jean-François Lyotard: Discours, Figure. Paris: Klincksieck, 1971. 
é entre a literatura escrita e audiovisual. É entre as potências criadoras (...) e os poderes de domesticação". ${ }^{3}$ Isso para não falar em Walter Benjamin e em Paul Ricoeur, que se dedicaram a compreender em muitos contextos a relação entre pensamento e narrativa. De qualquer modo, porém, permanece sem uma definição mais precisa o quanto a mudança radical de regime de relação com os fenômenos em geral traz consigo consequências decisivas para cada um dos respectivos modos aqui em questão. Assim como se costumou diferenciar na estética contemporânea o discurso e a figura, acentuando precisamente o quanto a tradução linguística da imagem traz consigo incontornavelmente uma mudança de registro e uma desconsideração da intraduzibilidade da imagem em palavra, também seria necessário dizer o mesmo no campo da experiência estética literária: por mais que seja estranho dizer isso, discurso e discurso são aqui coisas completamente diversas. Portanto, é preciso perguntar de antemão: é possível lidar filosoficamente com obras literárias sem ao mesmo tempo esquecer o quanto a palavra na literatura (discurso literário-ficcional) não se deixa traduzir em argumentos filosóficos (discurso lógico-argumentativo)? Se isso for possível, qual a repercussão dessa possibilidade sobre a obra de Dostoiévski em geral e sobre Os demônios em particular, uma vez que privilegiaremos antes de tudo essa obra em específico para discutir a condição contemporânea? A resposta a essas perguntas aponta para o que chamaremos em seguida de conteúdo fenomenológico radical da obra de arte literária, antes de tudo da contemporânea.

Não tenho como tratar senão de maneira breve e insuficiente do significado dessa expressão que norteará a leitura que proponho do texto dostoievskiano: o conteúdo fenomenológico da obra de arte literária. O que tenho em vista a princípio por tal expressão envolve antes de tudo dois elementos, que foram constantemente ressaltados no interior do projeto fenomenológico de autores como Husserl, Heidegger e Merleau-Ponty, entre outros. Em primeiro lugar, a suspensão de todos os posicionamentos ontológicos em geral, de todas as hipos-

3 Gilles Deleuze, Conversações. Tradução de Peter Pal Bart. São Paulo: Editora 34, 2010, p. 168. 
tasias, de todas as teorias que promovem uma mediação entre nós e os fenômenos propriamente ditos. É apenas uma tal suspensão, uma tal epoché, que torna possível pela primeira vez seguir o princípio dos princípios e alcançar uma "intuição originariamente doadora", ${ }^{4}$ um campo imediato de dação dos fenômenos. Em segundo lugar, a inserção originária da consciência no mundo. Para a fenomenologia em suas mais diversas faces, nem a consciência nem a existência podem ser pensadas como isoladas e encerradas em si mesmas, mas sempre se encontram originariamente enraizadas no mundo como o espaço mesmo de realização de suas possibilidades próprias de ser. É isso que fica claro tanto na fenomenologia constitucional de Husserl, quanto na descrição heideggeriana do ser do existente humano como ser-aí ou ser-no-mundo e na exposição merleau-pontyana do movimento mesmo de corporação como se constituindo sempre a partir de uma interação originária com o espaço em que tal corporação se dá. Esses dois elementos, então, encontram na obra de arte literária, antes de tudo naquela que não se faz mais a partir da pressuposição de que a obra seria realizada a partir do ponto de vista privilegiado do autor enquanto razão suficiente da criação, a sua máxima consumação. Se perguntarmos o que constitui propriamente uma obra literária, um romance ou mesmo um conto, por exemplo, essa pergunta mesma nos remeterá à experiência de uma constelação de elementos que, em sua interação mútua, constituem o cosmos próprio à narrativa. Não há na literatura apenas personagens que interagem, mas há sempre também espaços determinados, climas particulares, atmosferas constitutivas, vestimentas, particularidades históricas, intuitos expressos ou escusos, maquinações, confusões, incompreensões, atos malévolos, hipócritas ou benevolentes, preconceitos sociais etc. Tudo isso compõe em urdidura o tecido do qual emerge a vida literária, o espaço literário, para me valer de uma feliz expressão de Maurice Blanchot. ${ }^{5}$ Ao mesmo tempo, nenhum desses elementos é estabelecido de maneira

4 Edmund Husserl, Ideias para uma fenomenologia pura e para uma filosofia fenomenológica, $\S 24$, p. 43

5 Maurice Blanchot, L'espace litéraire. Paris: Folio, 1988. 
teórico-posicional. Não há na literatura simplesmente aquilo que constitui a visada teórico-categorial: o posicionamento espaço-temporal de algo e a subsequente interpelação discursiva do aspecto posicionado com vistas às categorias que explicam por que algo é como é e está onde está. Ao contrário, a ligação tensa entre os elementos complexos que constituem o mundo da escrita literária se mantém constantemente na pluralidade essencial de tais elementos, de tal modo que nunca é pela capacidade pura e simples de apreender o que caracteriza uma determinada cena que se pode acompanhar o que acontece em um romance. É claro que se pode reduzir o conteúdo narrativo a pequenos elementos cênicos: um encontro na casa do comendador, um passeio pelo parque, um beijo ao cair da noite, o assassinato oportuno de um amigo. É claro também que é sempre possível contar a história em uma sinopse bem-feita: um jovem casal tem relação de amor proibida pelos pais e se confronta com as consequências trágicas de lutar por sua relação. Tudo isso, porém, jamais consegue plenamente dar conta da matéria literária propriamente dita, uma vez que um romance nunca tem como ser pensado senão de maneira por demais empobrecida como uma série de acontecimentos que se passam na vida de seus personagens. Não. Todo romance é sempre muito mais do que isso. Como na famosa cena de Cidadão Kane de Orson Wells, há sempre uma superposição densa de planos na vida da literatura. O que temos aqui, portanto, é sempre um mundo que fenomenologicamente se apresenta ao leitor e que, exatamente por isso, precisa ser acompanhado na multiplicidade constelacional do que o constitui. Dito isso, podemos agora passar para o que nos interessa mais imediatamente aqui: ler a condição contemporânea a partir de uma obra em específico de Dostoiévski, ainda que possamos fazer uso vez por outra de algumas outras obras. O que nos importa desde o princípio é acompanhar a gênese do mundo, no qual habitam certos demônios que possuem uma proximidade absolutamente familiar com os demônios que hoje nos visitam. 


\section{Gênese e desenvolvimento da condição contemporânea: o mundo da supressão de todas as hierarquias valorativas e as consequências dessa supressão para a constituição mesma dos campos dé ação em geral}

O mundo no qual nos deparamos com os personagens de Os demônios é um mundo gestado em terra estrangeira em relação à Rússia de Dostoiévski, ainda que essa terra estrangeira tenha exercido desde sempre um imenso fascínio sobre a aristocracia russa. A terra na qual se enraíza o mundo dos demônios dostoievskianos é a terra fecundada pela Revolução Francesa e por uma certa compreensão do significado mesmo da igualdade universal entre os seres humanos. Foi a partir dessa ideia de igualdade universal que se combateram em seguida na Europa todas as posições sociais hereditárias, todos os títulos de nobreza, toda a vida ociosa daqueles que jamais precisaram fazer coisa alguma para aceder a uma situação absolutamente privilegiada e distinta. Juntamente com esse combate, porém, o que acabou se firmando como uma equação imediata do mundo pós-revolucionário foi a suposição de que a própria palavra aristocracia e de que a noção de nobreza que lhe era correlata não passavam de uma forma escamoteada de os detentores do poder perenizarem de maneira autodivinizada a iniquidade e a sordidez de uma dominação jamais sustentada senão na insensibilidade e na ignomínia. Em suma, a defesa intransigente da igualdade radical de todos os cidadãos e a contestação de todos os privilégios oriundos das desigualdades historicamente estabelecidas acabaram sendo compreendidas como se implicassem a impossibilidade e mesmo a ausência de sentido de toda e qualquer tentativa de alcançar uma ação capaz de trazer consigo uma distinção de essência para aquele que a acompanha como agente. De qualquer modo, porém, é preciso lembrar nesse ponto o que dissemos em nossas observações iniciais. Não se trata aqui de um tratado teórico sobre as consequências ético-políticas 
da Revolução Francesa sobre o mundo moderno e contemporâneo em diálogo com Os demônios. Trata-se, sim, muito mais da emergência de um mundo e das possibilidades da existência humana em meio às constelações daí provenientes. Nesse sentido, o decisivo é manter a atenção aqui na própria constituição do espaço narrativo, na própria vitalização dos personagens a partir de suas ambiências, de seus caminhos plurais e difusos, de suas interrelações, impasses, realizações etc. Dizer isso, contudo, não significa de imediato se perder na miríade de elementos em jogo no romance, mas não perder de vista o quanto certos elementos só se deixam plenamente apreender a partir de um papel preponderante desempenhado por um personagem e por sua situação narrativa. No caso de Os demônios, isso aponta antes de tudo na direção de Stiepan Trofímovitch Vierkhoviénski, o que mais tarde aparecerá simplesmente sob a alcunha de "o velho Vierkhoviénski".

Ao abrirmos as primeiras páginas de Os demônios, somos imediatamente apresentados a um personagem que, no decorrer da narrativa, possui um lugar antes secundário, ainda que esteja no centro de boa parte das narrativas, e que não parece a princípio ter uma ligação mais direta com a horda de figuras hediondas que povoam do início ao fim a matéria do romance. O narrador, por sua vez, tampouco procura esconder a princípio esse caráter secundário, mas o evidencia com uma insistência e uma radicalidade, que não deixa logo de saída qualquer dúvida quanto à mediocridade da figura. De início, o velho Vierkhoviénski é descrito como alguém que se distancia de São Petersburgo e se encaminha para a província por conta de uma suposta perseguição provocada pela periculosidade de certas ideias e pelo caráter transformador de determinados escritos. Como logo descobrimos, porém, a imagem de perseguido não foi senão produzida pelo próprio Stiepan Trofímovitch Vierkhoviénski para criar uma aparência de importância em torno de si:

Mas apenas se iniciara, encerrou-se a carreira de Stiepan Trofímovitch em consequência de um 'turbilhão de circunstâncias', como se comprazia ele em dizer. Na realidade, contudo, não houve nem 'turbilhão' nem mesmo 'circuns- 
tâncias', pelo menos no caso de que nos ocupamos. Agora somente, nesses últimos dias, vim a saber, com a maior estupefação, mas de fonte absolutamente segura, que bem longe de ser exilado na nossa província, como o acreditavam comumente, Stiepan Trofímovitch nem mesmo fora alguma vez objeto de qualquer vigilância. O que é, no entanto, o poder da imaginação! Ele próprio, toda a sua vida, acreditou sinceramente que sempre o haviam temido nas altas esferas, que seus menores passos eram conhecidos e contados, e que cada um dos três governadores, que se sucederam na nossa província, no curso dos vinte últimos anos, já chegava perfeitamente informado a seu respeito... ${ }^{6}$

O romance começa, portanto, com um personagem que constrói sua imagem a partir de um evento jamais ocorrido e de uma pretensão que acompanha precisamente tal imagem. Mas não é apenas no campo das atividades políticas e das ideias revolucionárias que o personagem vive constantemente daquilo que jamais realizou. Também no campo da poesia, da prosa e do pensamento em geral, tudo o que vem ao nosso encontro comprova incessantemente a mediocridade absoluta desse personagem com o qual se abre o romance. Bem, mas assim como provoca uma certa perplexidade constatar esse estranho início do romance, a razão pela qual esse início se dá pode ser complexa, mas não é incompreensível. Ela aponta para a inserção de um outro personagem chave no romance, por mais que esse personagem também se mostre como um personagem antes secundário. Falo de Varvara Pietrovna Stavróguina, mãe do demônio principal, do qual se distribuem e ramificam as diversas manifestações do demoníaco na obra: Nikolai Stavróguin. Como encontramos, porém, Varvara na abertura do romance? E em que medida sua presença compõe uma mistura bombástica com a de seu amigo Stiepan Vierkhoviénski? Por fim, como essas duas personagens se relacionam com o ambiente histórico da Revolução Francesa e com as repercussões propriamente ditas desse ambiente?

De uma maneira muito estranha, Stiepan Trofímovitch Vierkhoviénski é a figura chave para a entrada no mundo niilista de Os demônios. Vivendo de uma fama completamente fic-

6 Fiódor Dostoiévski, Os demônios, p. 798. 
tícia e de uma imagem de perseguido político, ele consegue alimentar constantemente a ilusão de que suas ideias e seus pensamentos são todos marcados por uma periculosidade que o colocaria na vanguarda das transformações bombásticas pelas quais passava a Rússia na segunda metade do século XIX. Diante de certo episódio ocorrido em meio à revolta dos camponeses, por exemplo, assim como de uma reação desproporcional por parte das autoridades locais, ele é

dominado por uma agitação tão violenta que ficamos, por nossa vez, assustados. Vociferava no clube que era preciso enviar efetivos mais numerosos, pedir telegraficamente reforços de outro distrito; correu à casa do governador a fim de afirmar-lhe que nada tinha com aquilo, suplicando que não o metesse, segundo o costume, naquele negócio, e propondo-lhe transmitir a quem de direito em Petersburgo sua declaração. ${ }^{7}$

Uma vez mais, porém, nem os camponeses tinham a menor ideia de quem era Stiepan Vierkhoviénski, nem havia tampouco alguém em São Petersburgo a quem ele pudesse se dirigir e que tivesse alguma relação com ele. Toda a descrição inicial da vida de Stiepan acentua reiteradamente sua impostura e sua total incapacidade de produzir o que quer que seja de realmente importante e decisivo. Varvara Stavróguina, por outro lado, é imprescindível para o surgimento mesmo da ambiência própria para a realização de tal impostura. É ela quem contrata Vierkhoviénski como preceptor de seu filho e que se nutre ao mesmo tempo da fama completamente infundada de seu funcionário e amigo para criar uma aura de intelectualidade e profundidade, que jamais encontra qualquer respaldo em uma ligação verdadeira com as coisas em jogo nas inquietações que cabem à vida espiritual. Com isso, na mesma medida em que o velho Vierkhoviénski se caracteriza pela empulhação mais deslavada, Varvara Stavróguina não passa de uma mulher abastada, que compra às custas de um fortuna herdada a aparência de saber. Entre essas duas dimensões, então, vem à tona a língua francesa e o ideário que desde o século XVIII passou a se ligar a essa língua. Há um provérbio alemão,

7 Idem, p. 823. 
que afirma: "o diabo mora nos detalhes". Em acréscimo poderíamos dizer que não é apenas o diabo, mas também a finesse compreensiva tem aí sua morada. São inúmeras as passagens do texto em que nos deparamos com a ligação entre Stiepan Vierkhoviénski e a França. Para além das passagens em que ele simplesmente cospe frases em francês, a fim de se distanciar simplesmente de um russo mediano, uma passagem chama muito a atenção. Descrevendo a atmosfera do grupo de amigos que giravam em torno de Vierkhoviénski, o narrador nos diz:

Quando o tédio se fazia demasiado, o judeu Liámchin, empregado subalterno dos correios, excelente pianista, punha-se a tocar o piano, imitando nos entreatos o grunhir do porco, a tempestade, as dores do parto e os primeiros vagidos do recém-nascido etc. etc. Só era convidado por causa disso. Se se bebia um pouco além da medida, o que não deixava de ocorrer, se bem que bastante raramente, chegava-se ao entusiasmo, e aconteceu-nos mesmo uma vez cantar em coro a 'Marselhesa' (itálico M. C.), acompanhados por Liámchin. Ignoro, todavia, se nos saímos bem...8

Eis aí a chave para a entrada nesse campo particular de relações que nos preparam para o encontro subsequente com a figura demoníaca por excelência, com Nikolai Stavróguin e seu papel central na construção da urdidura propriamente dita desse mundo, com o qual vamos paulatinamente nos familiarizando por meio do texto dostoievskiano. Cantar a Marselhesa evidencia o elemento de fundo que se encontra constantemente alimentando o universo pseudointelectual e mesmo pseudorrevolucionário que se achava por toda parte presente naquele momento na Europa e na Rússia. A revolução está lá. Não como uma incitação à luta, como um índice de um empenho profundo por transformação de todas as relações humanos, como o signo de um abalo radical e sem precedentes de todas as estruturas de injustiça constituídas a partir da mera naturalização do privilégio e da usurpação, mas como a coroação de uma noite de bebedeiras e pantomimas, de ausência completa de toda e qualquer relação entre a cena

8 Idem, p. 821 
patética de um grupo provinciano de amigos envolto em conversas insignificantes sobre temas pretensamente grandiosos e o dia de glória que teria chegado com o canto revolucionário. A questão, porém, que nos interessa antes de tudo não é apenas acompanhar a ambiência, na qual se gesta o mundo demoníaco, no qual vamos nos aprofundar em seguida, mas também avaliar em que medida esse mundo nasce de uma repercussão da supressão de todas as tensões hierárquicas, de todas as diferenciações entre os seres humanos em geral, sobre o problema da ação.

É possível pensar a princípio as hierarquias como se elas fossem instituídas única e exclusivamente a partir da subsistência formal dessas posições e de sua concessão imediata a pessoas marcadas pelo privilégio jamais natural, mas sempre naturalizado de se destacar como superiores. É esse tipo de pressuposto que leva, por exemplo, a que se olhe para a monarquia como algo em essência absurdo e que se suponha que a única monarquia legítima seria aquela em que se teria nascido como rei. A questão, contudo, é claramente mais complexa. No momento em que olhamos para a ação, para qualquer ação, o que temos não é simplesmente a ação e sua realização, mas toda ação sempre pode ser realizada de formas as mais diversas. De algum modo, poderíamos dizer que o que constitui propriamente a nossa condição humana é justamente o fato de que sempre podemos realizar uma ação do modo como ela não deveria ter sido realizada. Mesmo que a realizemos de maneira adequada, contudo, sempre há um imenso espectro de possibilidades de pensar tal realização de maneira mais ou menos plena. Algo sempre pode ser péssimo, ruim, malfeito, mediano, bom, excepcional, exuberante, incrível, perfeito etc. Os adjetivos estão aí para nos mostrar isso expressamente. Para que possa, contudo, haver um empenho efetivo na realização plena de uma ação; para que se possa buscar o que é bom e escapar do que é ruim, malfeito, mediano; em suma, para que seja possível concentrar todos os esforços na produção daquilo que precisa ser feito do modo como deve ser executado, é preciso antes de tudo que se possa pensar uma medida propriamente dita das ações em geral. Não se pode 
simplesmente apelar para aquilo que nós achamos ser o melhor ou o excepcional, uma vez que um tal apelo condenaria imediatamente todas as ações ao arbítrio extremamente volátil das existências humanas em geral. Isso para não lembrar da perspicaz menção cartesiana ao fato de que o bom senso seria a coisa mais bem distribuída do mundo, porque ninguém jamais acha que teria bom senso de menos. Transpondo essa frase para o nosso contexto, se cada um de nós tivesse de decidir a cada vez o que seria a medida da ação de acordo com os nossos critérios particulares de avaliação, o que teríamos seria justamente uma radical impossibilidade de pensar às últimas consequências o bom ou o ruim para além das idiossincrasias próprias a cada um. Nesse ponto, porém, é preciso lembrar o modo como a luta por direitos iguais para todos os seres humanos, o modo como o estabelecimento dos direitos universais do ser humano foram em parte recebidos pela história efeitual. Exatamente na medida em que se defendeu a igualdade formal de direitos entre todos os seres humanos, suspendeu-se ao mesmo tempo toda e qualquer possibilidade de se pensar como legítima uma distinção entre as ações, de tal modo que as noções de aristocracia e de nobreza passaram imediatamente a se mostrar como noções caducas e autorrefutatórias, como frutos ideológicos de um tempo que legitimava pura e simplesmente a exploração infundada dos seres humanos uns em relação aos outros. Como consequência dessa situação, por isso, o próprio problema da ação sofreu uma transversão de princípio, um giro louco e frenético. Uma vez que não se podia falar mais de nobreza, de melhores ou piores, tudo foi suposto como marcado por uma ausência total de orientação, por uma falta completa de peso e de medida, por uma impossibilidade de estabelecer o que se precisa fazer ou não fazer, o que se deve empreender ou não empreender. Criticar o rei veio à tona como um sinônimo de criticar todos os aqueles que se distinguem minimamente da massa amorfa dos mornos. Tal como na pantomima infinita dos personagens de À espera de Godot de Samuel Beckett, o mundo dos personagens de Os demônios também é marcado pela sensação de que não há simplesmente qualquer diferença entre as ações e 
de que qualquer um pode e deve fazer qualquer coisa, pois fazer ou não fazer perderam completamente a relevância. Dessa impressão emergem as diversas possibilidades de lida com a ação, possibilidades essas das quais tratarei aqui antes de tudo a partir de um acompanhamento das figuras de Stavróguin e de Kiríllov.

\section{Vozes extremas da condição contemporânea: da vida cínica à idealização de uma estranha revolução}

O que procuramos mostrar acima foi justamente em que medida o mundo de Os demônios emerge de um desdobramento muito particular da Revolução Francesa, desdobramento esse que acaba impactando de maneira exacerbada sobre a possibilidade de uma injunção existencial que traga consigo um empenho radical pela possibilidade mesma de realização da ação. Se jamais se alcança nada em ação alguma, uma vez que não há qualquer possibilidade de realizar de maneira melhor ou pior o que precisa ser realizado; se nunca podemos buscar coisa alguma por meio de nossas atividades em geral, uma vez que tudo está completamente destinado por princípio ao nada que é constitutivo de todas as atividades em geral; em suma, se as ações não produzem qualquer diferença de essência no campo mesmo no qual se dão, então o peso mesmo das ações se suspende e tudo parece padecer incontornavelmente de uma ausência completa de sentido. Não se experimenta, contudo, essa ausência de sentido de uma mesma forma, mas, ao contrário, ela traz consigo toda uma gama variada de possibilidades que se confunde, por sua vez, com a diversidade de figuras do demoníaco que compõe o mundo do romance dostoievskiano. Não há aqui como acompanhar em detalhes essa riqueza variegada de personagens e os espaços próprios a cada um deles. Em função das dimensões estruturais do presente artigo, preciso me contentar com uma redução do campo descritivo a duas possibilidades extremas que estão plasmadas justamente nas figuras de Nikolai Stavróguin e Ki- 
ríllov. Por mais próximos que sejam esses dois personagens, por maior que seja a unidade do espaço mesmo de realização de suas existências, suas maneiras de concretizar seus modos de ser nesse espaço são marcados por uma radical separação, por uma incompatibilidade máxima e por um abismo intransponível. Por um lado, todos os dois partem da vacuidade de todo e qualquer empenho pela vida. Todo fazer aqui é essencialmente nada, na medida em que todo fazer está de antemão condenado à dissolução subsequente de tudo aquilo que veio a ser e à indiferença completa dos esforços, por mais sinceros e intensos que eles possam ser. O nada de toda ação, por outro lado, é experimentado, contudo, por cada um dos dois de maneira francamente oposta. Em primeiro lugar temos a enigmática figura de Stavróguin. Em segundo lugar, a figura inusitadamente messiânica de Kiríllov. Vejamos como vão se constituindo as experiências desses dois personagens.

A chave para a compreensão de Stavróguin é dada pelo próprio narrador de Os demônios, ao nos apresentar o personagem como marcado precisamente pelo fato de levar o que podemos chamar de uma vida irônica. E em que consiste, afinal, uma vida irônica? Uma vida irônica é aquela em que toda e qualquer possibilidade de seriedade se vê por princípio rompida, em que impera de saída e constantemente uma indiferença radical em relação a toda e qualquer possibilidade de existência, uma vez que todo o campo existencial do personagem solapa de antemão a possibilidade de crença na ação. Por isso, sua ironia se confunde com uma impossibilidade de crença ou descrença no que quer que seja, de disposição diversa em relação ao que quer que se dê. Dito de maneira sintética, quando Stavróguin crê, ele não crê que crê; e quando ele não crê, ele não crê que não crê. Desde a entrada em cena de Nikolai Stavróguin no romance, portanto, todo um espaço de incompreensão de suas ações se instaura, uma vez que se parte desde o princípio da ideia de que ele buscaria algo por meio de suas ações. Suas atitudes completamente de veneta, seu comportamento errático e a oscilação perene entre o despojamento e a ruptura com os padrões mais vigentes de moralidade levam as pessoas até mesmo a pressupor algu- 
ma doença mental, algum desequilíbrio psíquico que poderia responder precisamente pela ilogicidade constitutiva de seu ser. A incompreensão, no entanto, está assentada aqui sobre um pressuposto claramente marcado por um horizonte tradicional de determinação das ações em geral. É porque sempre se supõe já uma intenção específica nas ações, que se consideram loucas as ações nas quais não se consegue apreender nenhuma intenção específica. Para que se pensem as ações a partir da lógica das intenções, dos interesses, dos jogos de poder e de domínio, é antes de tudo necessário, porém, que se parta do pressuposto de que as ações se realizariam em um campo plenamente dotado de sentido. Seja no campo da política, das artes em geral, da vida comum dos cidadãos e de seus respectivos projetos de concreção de seus anseios e sonhos, para que se possa buscar alguma coisa por meio da ação, é preciso que já se parta da suposição de que é possível alcançar alguma coisa com a ação. Exatamente essa suposição, contudo, se encontra suspensa no caso de Stavróguin. Desde o princípio, jamais se alcança nada para ele por meio da ação, de tal modo que a própria lógica das intenções é imediatamente suspensa na origem. Não importa o que se faça, jamais se consegue chegar a lugar algum com aquilo que se fez. Bem, mas se nada leva a lugar algum e se estamos de um modo ou de outro condenados a agir, como lidar com as ações que incontornavelmente precisamos realizar? O cinismo e a ironia em seu aspecto niilista parecem se mostrar como uma opção natural. Se nada leva a coisa alguma e se todas as ações são igualmente iníquas, então o ser humano esclarecido é precisamente aquele que superou a ingenuidade de todo e qualquer pensamento heroico. Da superação dessa ingenuidade, por sua vez, emerge uma estranha sensação de superioridade. E é aqui, então, que precisamos enraizar o foco de nossa descrição de Stavróguin. O que temos em seu caso não é simplesmente a percepção de que todo fazer é nada. Tal posição tenderia de início a gerar algo assim como uma existência melancólica, ao estilo de Meursault, o personagem dostoievskiano-nietzschiano do romance $O$ estrangeiro de Albert Camus. Sem poder se fiar em toda e qualquer ação, uma possibilidade seria precisamente 
se deixar levar pela vida e se firmar da mesma forma em uma espécie de inércia existencial. Stavróguin é claramente mais do que isso. Como sua descoberta inicial do sem sentido da existência vem desde o princípio acompanhada pela estranha constatação de que os seres humanos modernos continuam constantemente vivendo como se fosse possível alcançar algo por meio da ação, sua existência é constantemente marcada por uma soberba e por um prazer mórbido em ver todas as coisas grandes se desfazendo. Por um lado, ele leva constantemente uma existência cínica e irônica. Nada do que faz ou não faz é movido por alguma crença, por alguma fé, por algum agenciamento sincero e desprendido. Tudo o que ele faz, ele faz a partir da pressuposição de que fazer ou não fazer se equivalem radicalmente. Por outro lado, porém, ter alcançado esse grau de clarividência e de lucidez o eleva a um grau mais intenso de participação nos acontecimentos em geral. Para Meursault, por exemplo, aceitar uma proposta de emprego, na qual ele poderia ganhar mais e viver em uma cidade mais rica como Paris não fazia qualquer sentido. Não porque faria algum sentido não aceitar tal proposta. Para ele, não faz sentido nem aceitar nem não aceitar a proposta. Se ele não aceita, portanto, é apenas porque a mudança de emprego acarretaria transformações desnecessárias. No final das contas, para ele tanto faz. Como tanto faz, porém, é sempre melhor deixar as coisas como estão e não fazer. No caso de Stavróguin, tudo é completamente diferente. Se nada faz sentido, então a vida é uma comédia de erros, na qual o único ser próprio é aquele que sabota o tempo inteiro as convenções, a ordem sedimentada dos comportamentos, o caráter supostamente sagrado da vida etc. Assim, ele não crê nem não crê em coisa alguma, mas encontra precisamente na corrosão de todo e qualquer empenho possível, de toda e qualquer crença nas ações o télos estrutural de sua existência. É isso, por exemplo, que uma cena chave evidencia. Trata-se da cena conclusiva da obra, em que Stavróguin se encontra com o padre Tíkhon e confessa para ele seus crimes, em especial a sedução de uma menina e a indução subsequente de seu suicídio. Para Dostoiévski, a confissão é, como para toda uma tradição cristã que remonta a Santo 
Agostinho, um momento de máxima humildade, de abertura sincera do coração humano, finito, em face de Deus. Uma vez que Deus é omnisciente, a ideia mesma de uma confissão parece padecer de todo e qualquer sentido. Em que medida se deve confiar a Deus aquilo que Ele não apenas sabe de antemão, mas sabe em seu valor eterno?!? A resposta parece passar precisamente pela humildade. Eu sei que Deus já sabe o valor eterno do que vou contar, mas conto assim mesmo, para mostrar a pureza de minhas intenções. Ao escutar, porém, a confissão de Stavróguin, o sábio santo descortina o fundo de sua exposição. Não era por humildade que ele tinha ido se confessar, mas por soberba. Com isso, a consequência mais direta não poderia ser outra senão: a constatação de que ele cometeria tudo de novo: "- Que tem? Que tem? - Repetiu Stavróguin, precipitando-se para ele, a fim de ampará-lo. Parecia-lhe que ele ia cair. - Vejo... vejo como se fosse a realidade - exclamou Tíkhon, com uma voz que transpassava a alma e com uma expressão de dor intensa, - vejo que jamais, pobre moço perdido, esteve o senhor tão perto, quanto neste momento, de cometer um novo crime maior...". ${ }^{9}$ E é exatamente essa a chave do personagem Stavróguin: ele não leva apenas uma existência cínica e irônica, mas retira de seu cinismo e de sua ironia a fonte suprema de sua presunção, de sua soberba, de sua sensação de estar acima de todos os homens e de sua crença ingênua em que seria possível alcançar algo por meio de empenho e compromisso. Nesse ponto, o mundo de Stavróguin é próximo do mundo de Brás Cubas em seu capítulo das negativas. A diferença é que Stavróguin está vivo. Por isso, de acordo com o vaticínio do velho sábio, ele cometeria todos os crimes de novo: porque, ainda que não veja qualquer sentido na ação, ele retira da destruição de tudo o que é puro um sentido último para a sua existência, uma sensação de superioridade e poder. Frente a Stavróguin, então, Kiríllov se revela como uma possibilidade igualmente extrema, mas oposta.

Exatamente como Stavróguin, Kiríllov também se mostra como uma figura emergente da situação aberta pela recepção

9 Fiedor Dostoiévski, Os demônios, p. 1375. 
da Revolução Francesa. Não há qualquer sentido em uma existência condenada desde o princípio à fugacidade, à morte, à indiferença e à ausência de qualquer possibilidade de alcançar algo por meio da ação. Diferentemente de Stavróguin, porém, a descoberta dessa condição existencial não leva Kiríllov simplesmente a se colocar em uma posição supostamente esclarecida e superior, que tornaria possível em seguida extrair um prazer sádico de acompanhar a dissolução, a destruição, a corrosão de todos os grandes e elevados empenhos. Tal como explicita Nietzsche em uma passagem de um capítulo central de Assim falou Zaratustra intitulado "Da redenção", há sempre um risco de que a experiência da mutabilidade da vida se transforme em uma condenação da vida e esse risco é muito mais característico do primeiro do que do segundo personagem: "E, porque no querente mesmo existe sofrimento pelo fato de não poder querer para trás - então o próprio querer e a vida inteira deveriam - ser castigo. E uma nuvem após outra rolou sobre o espírito: até que finalmente o delírio pregou: 'Tudo perece, tudo merece perecer"'. ${ }^{10} \mathrm{Bem}$, mas se o ponto de partida de Kiríllov é de certa forma o mesmo, qual sua grande diferença em relação à soberba da pretensa descoberta do sem sentido do existir em Stavróguin? Não há nenhuma redenção possível, na medida em que não há mais nenhuma transcendência autonomizada tanto quanto não há nenhuma ação capaz de nos devolver à situação em que nos víamos quando tudo era acompanhado por um sentido transcendente plenamente positivo. Não há mais nenhuma possibilidade de a ação nos levar para alguma posição distintiva no mundo e não há tampouco qualquer possibilidade de escapar de tal campo de ação. Essa é a situação diante da qual estão de certa forma tanto Stavróguin quanto Kiríllov. Se a soberba é a saída de um, porém, a possibilidade de liberdade é a saído do outro. Até aqui, essa é a posição que nos é apresentada por Kiríllov, o homem se viu preso, encarcerado, vigiado constantemente por um olhar que nada deixava passar. Todas as suas ações eram imediatamente desveladas em seu caráter vil, sórdido, baixo, falível, parcial, inconstante etc. Como a medida da existência

10 Friedrich Nietzsche, Assim falou Zaratustra, "Da redenção", p. 134. 
era Deus e como o olhar divino jamais deixava sem escrutínio os momentos mais diversos do existir, o ser humano se achava constantemente preso a uma medida que o assolava e oprimia. Nada do que faço me leva à plenitude que só é possível alcançar na reconciliação com o corpo do criador, na abertura para a vida eterna. Nas palavras do próprio Kiríllov, até aqui Deus podia tudo e o ser humano não podia nada. A questão, porém, é que a Revolução Francesa abriu, por fim, as portas de um processo que não tinha mais como ser interrompido. Não é que o pensamento revolucionário simplesmente equipara todos os seres humanos, uma vez que os torna por princípio iguais. Mas a própria possibilidade da equalização emerge da supressão de toda e qualquer medida que surgia tradicionalmente da presença de Deus no mundo. Todos são iguais, portanto, porque Deus morreu, porque não há mais qualquer possibilidade de reter a transcendência como polo de orientação e valoração da totalidade da vida. A morte de Deus, porém, expressão que se articula de maneira expressa apenas no interior do pensamento nietzschiano, mas que se acha de certa forma antevista na obra de Dostoiévski, não é um evento simples, que pode ser tratado como um fato. Por mais que ela tenha se dado e por mais que as possibilidades do existir contemporâneo provenham daí, ela precisa necessariamente de vozes capazes de verbalizar em conteúdo concreto suas consequências. Tal verbalização, então, aponta no caso de Kiríllov para uma estranha concepção do suicídio.

De acordo com Kiríllov, houve até aqui na história da humanidade apenas dois tipos de suicidas. Em primeiro lugar, aqueles que se suicidavam, porque tinham uma razão para se suicidar (a perda de um amor, a falência nos negócios, a supressão das condições mínimas de vida); e, em segundo lugar, aqueles que se matavam, porque já não tinham mais nenhuma razão para viver (ausência de sentido, depressão, tédio profundo). Faltava ainda, porém, segundo ele, o tipo perfeito de suicida: aquele que se suicidaria para entregar ao homem a sua plena liberdade. Kiríllov, por mais estranho que isso possa parecer, é ao mesmo tempo uma figura demoníaca, um dos desdobramentos possíveis do velho Vierkhoviénski, na mesma medida 
em que ele é uma possível experiência do Cristo dostoievskiano. Uma experiência claramente niilista desse Cristo, e, com isso, milhas de distância afastada das figuras de Míchkin de O idiota e de Sônia de Crime e castigo, mas ainda assim uma tal experiência Perguntemos, então: em que medida o suicídio pode ser, para Kiríllov, um instrumento de libertação do homem? Como pensar um Cristo suicida? Para respondermos a essas perguntas, é preciso ter em vista o que dissemos acima. Deus não era simplesmente o fundamento último da totalidade e a razão de ser de todos os entes para a tradição cristã, ele também era um signo de corrupção e de pequenez da existência. Por isso mesmo, essa é a linha de raciocínio de Kiríllov, a mera presença de Deus tornava o ser humano prisioneiro. O ódio à testemunha está, assim, presente incessantemente no modo como se dá a argumentação kirilloviana. Como Deus acompanha com o seu olhar todos os acontecimentos humanos e como vê tudo o que se dá no tempo na eternidade, ele marca com um estigma todas as possibilidades da existência. Se há Deus, portanto, não há liberdade. Se o Cristo veio ao mundo para trazer liberdade ao ser humano, se essa liberdade foi pensada de saída por meio precisamente daquilo que se revelou agora como prisão, o verdadeiro Cristo ressuscitado é aquele que não mais se sacrifica na via crucis, mas aquele que se sacrifica por meio de sua autodestruição. Morrer para libertar o ser humano do olhar de Deus. Essa é a posição de Kiríllov. A questão, contudo, é que essa liberdade não reconcilia o ser humano com a terra, nem é capaz tampouco de devolver à existência sua plena medida. Não é nunca suprimindo a testemunha, que se suprime ao mesmo tempo também o crime. O que falta a Kiríllov, portanto, é exatamente o mesmo que falta a Stavróguin, a experiência de uma possibilidade de vida, que não seja marcada na origem pela incompletude, pela falta, pelo ressentimento e pela vingança. Exatamente isso, porém, é o que caracteriza o niilismo inerente à estranha revolução concebida por Kiríllov. Aquilo de que mais se precisa não é senão da descoberta de uma medida própria ao existir. 


\section{Caminhos que se abrem a partir de Dostoiévski}

O mundo dos personagens dostoievskianos é certamente um mundo próximo e distante. Seus problemas são por um lado os mesmos que os nossos: a dificuldade máxima de lidar com a existência, quando todas as possibilidades de se pensar uma transcendência autonomizada se suspendem, quando nos vemos radicalmente reduzidos a esse mundo que é, ao fim e ao cabo, o único mundo que há. Por outro lado, se os nossos problemas são os mesmos, as constelações nas quais esse problema aparece são completamente diversas. Se a Revolução Francesa teve um papel central nos discursos acerca da igualdade universal entre os homens e se ela promoveu ao mesmo tempo uma sensação de indistinção radical entre todos, o que temos hoje no mundo contemporâneo é muito mais a retenção de estruturas hierárquicas por vias difusas. Em meio a uma perspectiva cada vez mais dominada por interesses mercadológicos e diante de um mundo intensamente absorvido por uma volatilização da existência e por uma diluição da vida em processos abstratos de realização, não há como pensar a absoluta ausência de parâmetros diferenciadores entre os homens como o nosso principal dilema. Há para nós distinções demais, ainda que essas distinções sejam estabelecidas por elementos distintivos viciados e viciosos. Se o niilismo ateu vinha à tona ali como um risco de dessacralização máxima do real, como uma ameaça cada vez mais iminente de uma entrada em um período de total desencantamento do mundo e de predomínio quase absoluto da racionalidade científica sobre todas as nossas possibilidades de ser em geral, o nosso tempo nos levou em direção a um outro tipo de dessacralização tanto quanto a outras possibilidades de desencantamento. Não é mais o ateísmo durante tanto tempo associado ao comunismo que nos assola, mas antes muito mais as formas de dessacralização que ganham corpo precisamente nas formas de concreção religiosas marcadas antes de tudo pela comercialização da fé, pela mercadologização da crença, pela transformação 
das igrejas em geral em campos de extensão da exploração e em promoção de uma experiência catártica e hipnótica. Tampouco a ciência se faz hoje presente em sua capacidade ímpar de desencantar os fenômenos em geral. O que temos hoje é antes uma relação inversamente proporcional entre o interesse cada vez mais crescente pela simples utilização automática dos artefatos científicos e a absoluta indiferença, por vezes mesmo a hostilidade radical em relação a teorias científicas como um todo. Ao mesmo tempo, assim como acontece com Tolstoi em Ana Karenina, todas as situações ligadas à honra dos personagens, às traições, aos arranjos voltados para a manutenção das aparências etc. tampouco possuem um sentido ainda hoje para nós, a não ser em certos nichos conservadores bastante artificiais e retrógrados. O mundo de Dostoiévski, portanto, nos é distante. $O$ cinismo de certos personagens, porém, sua desorientação, sua incapacidade de lidar com o destino em meio a uma realidade cada vez mais complexa, as tensões oriundas da necessidade de encontrar uma medida para as ações, uma medida que não conseguimos encontrar pura e simplesmente em nós, na razão, em Deus e no Cristo, em qualquer dimensão de transcendência que pudesse se apresentar, no Bem em suas mais diversas variantes, tudo isso faz de seu mundo ao mesmo tempo um mundo próximo, um mundo em que, lutando com seus dilemas, com seus erros, com suas encruzilhadas e travessias, os personagens de ontem revelam possibilidades de um agir voltado para o amanhã.

\section{Referências bibliográficas}

BLANCHOT, Maurice. L'espace litéraire. Paris: Folio, 1988.

BORNHEIM, Gerd. Sartre. São Paulo: Perspectiva, 2011.

DELEUZE, Gilles. Conversações. Tradução de Peter Pál Pelbart. São Paulo: Editora 34, 2010.

DOSTOIÉVSKI, Fiódor. Obras completas em três volumes. São Paulo: Aguilar, 1987.

HUSSERL, Edmund. Ideias para uma fenomenologia pura e 
para uma filosofia fenomenológica. Zurique: Fischer, 1988.

NIETZSCHE, Friedrich. Assim falou Zaratustra. Tradução de Paulo César de Souza. São Paulo: Companhia das letras, 2005.

Recebido em: 09/03/2021 Aceito em: $15 / 04 / 2021$

Publicado em abril de 2021 